MACIEJ FALSKI

Uniwersytet Warszawski

e-mail: mf.falski@gmail.com

\title{
Rudan $^{\mathrm{TM}}$, czyli strategie pisarzy w sferze publicznej
}

\begin{abstract}
Rudan $^{\mathrm{TM}}$, or Writer's Strategies in the Public Space

Vedrana Rudan, a Croatian writer, publicist, and blogger, has become a famous public person, thanks to her constant presence in different media. Her strategies are presented in the paper as a conscious branding. It means that the writer tries to be present not only in the literary field, but successfully uses different channels of communication, in order to gain public recognition. Main ways of writer's communication are discussed in the paper, among them: a blog, social media, TV performances, and author sessions. The paper argues that Rudan are not an example of celebrity, but her drive to recognition is related more with an ideological involvement, very close to the idea of social responsibility of intellectuals. Her strategies aim to influence the audience, create an emotional community and protest against the political reality in Croatia.
\end{abstract}

Keywords: Vedrana Rudan, public sphere, branding, intellectuals, Croatian literature.

Słowa kluczowe: Vedrana Rudan, sfera publiczna, branding, intelektualiści, literatura chorwacka.

Kim jest pisarz: głosem historii, sumieniem narodu, zwierciadłem świata? A może rzemieślnikiem, konkurentem w walce o zainteresowanie odbiorców, graczem na rynku? Wszystkie te postawy w którymś momencie dochodziły do głosu. Znane są pretensje wieszczów do przewodzenia duszom narodów, ale też historie autorów ślących ponaglenia do wydawców z prośbą o wypłatę zaliczek. Romantyczno-modernistyczny model literatury ugruntował przekonanie o tym, że pisarz jest postacią wyjątkową, obdarzoną nadnaturalnymi przymiotami ducha i oderwaną od codzienności - celnie sparodiowane przez Andrzeja Bursę w wierszu Poeci ${ }^{1}$. W potocznym odbiorze, kształtowanym głównie przez tradycyjny

1 Poeta cierpi za miliony

od 10 do 13.20

O 11.10 uwiera go pęcherz 
kanon szkolny, pisarz wciąż zajmuje, jak się wydaje, wyjątkowe miejsce przewodnika, kogoś, kto wie więcej i patrzy głębiej niż zwykli ludzie. Z drugiej strony rywalizuje $\mathrm{z}$ tym wyobrażenie pisarza - autora bestsellerów, gwiazdy portali plotkarskich, troszczącego się bardziej o opakowanie niż o zawartość książek, błyskotliwie skrytykowane przez Dubravkę Ugrešić na przykładzie występu Joan Collins na targach książi².

W niniejszym artykule chcę się zastanowić, w jaki sposób tradycyjne wyobrażenie roli społecznej pisarza zderza się $\mathrm{z}$ wszechobecną wiarą $\mathrm{w}$ potęgę rynku, nieco na wyrost nazywanego wolnym rynkiem. Czy modele zachowań rynkowych są zagrożeniem, czy szansą dla literatury? Czy można utrzymać przekonanie o wyjątkowym charakterze pracy pisarskiej, jeżeli za zasadnicze kryteria oceny wytworów sztuki uzna się sprzedawalność i oglądalność? Oczywiście trudno odpowiedzieć na tak postawione pytanie, jednakże analiza działań głośnej chorwackiej pisarki Vedrany Rudan pozwoli na ilustrację problemu i wskazanie możliwych linii dyskusji o strategiach pisarskich w sferze publicznej ${ }^{3}$.

Vedrana Rudan urodziła się w 1949 roku. Pracowała przez lata jako dziennikarka radiowa w Radio Rijeka; po zwolnieniu ${ }^{4}$ w 1991 roku pisała felietony i artykuły dla prasy opozycyjnej, najdłużej współpracując z tygodnikiem „Nacional”. Pierwsza powieść, Ucho, gardło, nóż (Uho, grlo, nož, 2002), przyniosła jej znaczny rozgłos nie tylko w Chorwacji. Od tego czasu opublikowała kilka powieści oraz zbiór esejów, zarówno zyskując uznanie, jak i wzbudzając niechęć; szczególną popularnością cieszy się w Serbii. Rudan stała się też postacią medialną, często występuje w programach publicystycznych, wypowiada się w telewizji i radiu.

Spróbuję opisać jej działalność publiczną jako świadome budowanie marki ${ }^{5}$. Marką w jej przypadku jest ona sama, imię i nazwisko: Vedrana Rudan; to syg-

\section{wychodzi \\ rozpina rozporek \\ zapina rozporek \\ Wraca chrząka \\ i apiat' \\ cierpi za miliony}

Tekst udostępniony na portalu www.literatura.wywrota.pl: http://literatura.wywrota.pl/wiersz-klasyka/3421-andrzej-bursa-wybor-wierszy.html (dostęp: 23.02.2017).

2 Zob. D. Ugrešić, Czytanie wzbronione, przeł. D.J. Cirlić, Izabelin 2003.

3 Pisanie Rudan wiąże się także z kwestią (pozornego) zanikania granicy między literaturą elitarną i popularną; debiutowała ona jako pisarka w interesującym okresie eksperymentu promocyjno-literackiego, jakim był Festival Alternativne Književnosti (FAK, Festiwal Literatury Alternatywnej), próbujący wykorzystać środki nowoczesnej kampanii marketingowej i nowe kanały komunikacji z czytelnikami do promowania dobrej literatury. Więcej na temat tego kontekstu zob. M. Kolanović, Udarnik! Buntovnik? Potrošač... Popularna kultura i hrvatski roman od socijalizma do tranzicije, Zagreb 2011, zwłaszcza s. 163-167.

4 V. Rudan została zwolniona za krytykę prezydenta Franja Tuđmana w 1991 r. Była jedną z pierwszych ofiar politycznej czystki w chorwackich mediach po dojściu do władzy nacjonalistycznej partii HDZ. Jak sama pisze, krytykowano ją też i poddano ostracyzmowi ze względu na to, że jej drugi mąż jest Serbem. Przez kilka lat zmuszona była utrzymywać się z rozmaitych zajęć, niezwiązanych $\mathrm{z}$ dziennikarstwem i mediami.

5 Literatura na temat tworzenia marki (branding) jest bardzo bogata. Odwołuję się do modelu opisanego na podstawie literatury przedmiotu w artykule Sandry Huzak, Stvaranje nove marke 
natura autorki książek, ale też coś więcej. Logo postaci, osoby publicznej, która wypowiada się poprzez różne kanały komunikacyjne, tworzy strategie kontaktu z czytelnikami i publicznością, a przy tym staje się jedną z osób coraz chętniej zapraszanych do mediów w sprawach niezwiązanych z literaturą. Nie mogę odpowiedzieć na pytanie, czy taka strategia ma zwiększać sprzedaż książek, czy też pozwala na dotarcie z przekazem do szerszej publiczności; sądzę, że nie jest to właściwie postawiona kwestia. Można się jednak przyjrzeć, jak rodzi się pisarz jako osoba publiczna. Być może po prześledzeniu rozmaitych rodzajów aktywności chorwackiej pisarki uda się opisać dzisiejsze wcielenie intelektualistki zaangażowanej ${ }^{6}$, jakkolwiek to paradoksalnie brzmi w punkcie wyjścia.

\section{Blog}

Zapewne doświadczenia dziennikarskie zdobyte w radiu oraz przy regularnym pisaniu felietonów uświadomiły Rudan, jak ważny jest stały kontakt z czytelnikami. Od 2010 roku prowadzi ona bloga, z przerwą od 2015 do 2016 roku. Wpisy pojawiają się regularnie; poświęcone są przeważnie aktualnym wydarzeniom z Chorwacji i świata. Czytelnik rozpozna w nich charakterystyczny styl autorki: dosadne wypowiedzi pełne wulgaryzmów, posługiwanie się paradoksem, poruszanie stałych tematów, takich jak prawa kobiet, sytuacja młodych na rynku, polityczne i ekonomiczne uzależnienie Chorwacji, ostra krytyka Kościoła katolickiego itd. Blog Rudan charakteryzuje duży ładunek polityczności, aktywne obserwowanie oraz komentowanie wydarzeń i procesów dziejących się w sferze publicznej. W jednym z najbardziej poruszających tekstów, w którym żegnała się (jak się okazało - czasowo) z czytelnikami, autorka pisała:

Do pisania bloga skłoniło mnie to, że wojna jest za nami, powinniśmy wszyscy walczyć o lepsze życie, wybaczyć jedni drugim, jakkolwiek by to było trudne, dlatego że normalny człowiek nie może się do śmierci karmić nienawiścią. Myślałam, człowiek bywa głupi, że coś mogę zrobić. Pretensjonalna idiotka. Miałam nadzieję, że ludzie na obszarze byłej Jugosławii zrozumieją, że ich wrogami są ci, którzy ich nowo stworzone państwa trzymają w kieszeni, a nie ci, którzy w odmienny sposób modlą się do boga?

turističeke destinacije: primjer Hrvatske, „Acta Turistica Nova” 3 (2009), 2, s. 227-268; zob. też D. Aaker, Aaker on Branding: 20 Principles that Drive Success, New York 2014.

6 Pojęciem pisarza zaangażowanego i intelektualisty posługuję się w ślad za tradycją francuską, opisaną przez Christophe'a Charle'a (La naissance des ,intellectuels”, 1880-1900, Paris 1990), a najpełniej chyba ucieleśnioną przez Jeana-Paula Sartre'a (Qu'est-ce qu'une littérature engagée?, Paris 1946). Zaangażowanie intelektualisty oznacza, że czuje on obowiązek zabierania głosu publicznie w sprawach związanych z wolnością, dobrem publicznym, wartościami ważnymi dla ogółu, i czuje do tego prawo na mocy wyobrażenia o pozycji i funkcji intelektualistów w społeczeństwie (wyobrażenia krytycznie opisywanego m.in. przez Pierre'a Bourdieu, por. jego Reguly sztuki (2001) albo Ontologie politique de Martin Heidegger (1998)).

„Na pisanje bloga potakla me činjenica da je rat iza nas, da bismo se svi morali boriti za bolji život, jedni drugima oprostiti ma kako to teško bilo zato jer se normalan čovjek ne može dovijeka hraniti mržnjom. Mislila sam, čovjek zna biti glup, da ja nešto mogu učiniti. Pretenciozna glupača. Nadala sam se da će ljudi na području Jugoslavije prepoznati da su im neprijatelji oni koji 
„Myślałam, że coś mogę zrobić” - te słowa zdradzają intencję autorki: pragnienie oddziaływania na czytelników, pisania, które zmienia odbiorców i powoduje w nich jakąś przemianę, ideową, etyczną, polityczną. Wpisy na blogu są w pewnym sensie kontynuacją felietonistyki, ale z dwiema ważnymi różnicami. Po pierwsze, na swoim blogu Rudan nie jest od nikogo zależna, nie musi brać pod uwagę profilu pisma, polityki redakcji, powiązań między właścicielami tytułu a rynkiem. Taka postawa daje znacznie większą swobodę, ale też całkowitą odpowiedzialność ponosi autorka wpisów. Po drugie, a to kwestia ważniejsza, blog jest kanałem pozwalającym na interakcję z odbiorcami. Wpisy Rudan osiągają wysoki poziom odsłon (rzędu kilku-kilkunastu tysięcy) i większość z nich opatrzona bywa wieloma komentarzami. Wywiązuje się swoisty dialog, ale nie on jest najważniejszy. Komentarze w większości potwierdzają diagnozy Rudan, częste są wyrazy sympatii czy podziwu. W tej wymianie wpisów dominuje ton emocjonalny i wydaje się, że właśnie ten wymiar jest najistotniejszy w blogowej interakcji. W cytowanym już wpisie Rudan przyznała: „A jednak będzie mi was brakować. Pozdrawiam was, będę trochę patetyczna na koniec, z całego serca, które do śmierci będzie biło tylko na cześć dobrych ludzi”" Jest w tym nuta przywiązania do czytelników, dla których pisała przez pięć lat i którzy często zdradzali swoje zainteresowanie czy wręcz przywiązanie. A zatem istotnym wymiarem tworzenia osobowości - tworzenia marki - jest wywołanie pozytywnych emocji i tworzenie grupy zwolenników połączonej nie tyle (nie tylko) przez przekonania ideowe, ile na równi przez więzi sympatii czy oddania9.

Blog Vedrany Rudan nosi tytuł Jak umrzeć bezstresowo (Kako umrijeti bez stresa $)^{10}$, co zabawnie nawiązuje do popularnych poradników, chociaż w tym wypadku treść jest całkowicie odmienna: autorka opisuje głównie problemy, zagrożenia i patologie sfery publicznej we współczesnej Chorwacji. Od początku działania blog rozszerzył się do formatu osobistego portalu pisarki. Dominują wciąż wpisy blogerki, ale na pozostałych podstronach można znaleźć działy: „Książki”, zawierający omówienia i fragmenty wszystkich utworów Rudan; „Galerię” ze zdjęciami prasowymi autorki; kontakt w sprawach związanych z prawami autorskimi, spotkaniami itd.; „International” z wyborem poświęconych Rudan tekstów opublikowanych za granicą. Strona została profesjonalnie przygotowana, jest graficznie dopracowana, zawiera też wszystkie elementy konieczne do nawiązania relacji z instytucjami czy osobami na rynku medialnym i literackim. Blog

su njihove novokomponirane države strpali u džep a ne oni koji se na drugačiji način bogu mole". V. Rudan, Odustajem, 24.08.2015, http://www.rudan.info/odustajem/(dostęp: 6.01.2017).

8 „Ipak, nedostajat ćete mi. Pozdravljam vas, da budem malo patetična na kraju, od srca koje će do smrti kucati samo u slavu dobrih ljudi”. Ibid.

9 Komunikacja poprzez bloga różni się od strategii wywierania wpływu przez media przede wszystkim zachowaniem (pozorów) aktywnego odbioru przez czytelników. Nie są oni jedynie biernymi słuchaczami, jak w przypadku telewizji, czy czytelnikami gazet, lecz zyskują możliwość komentowania, krytykowania bądź wyrażania poparcia. W ten sposób odbiorcy bloga stają się rodzajem wspólnoty wyróżnionej z anonimowej widowni. Por. D. McQuail, Teoria komunikowania masowego, przeł. M. Bucholc, A. Szulżycka, Warszawa 2008, s. 391-411.

10 Adres bloga: http://www.rudan.info. 
przerodził się zatem w portal autorki, jej internetową wizytówkę, niezbędną przecież współcześnie do prowadzenia interesów.

„Trudno być sławnym i potężnym tak jak ja. Mam najczęściej czytany blog na Bałkanach..." - pisze w jednym z postów Vedrana Rudan ${ }^{11}$. Nie udało mi się dotrzeć do żadnych statystyk potwierdzających te słowa w odniesieniu do Bałkanów czy Chorwacji, niewątpliwie jednak jej blog cieszy się popularnością. Najgłośniejsze wpisy, komentowane przez media, osiągnęły dotąd liczbę odsłon rzędu 65 tysięcy (Mladi, idete mi nakurac, 5.01.2017) czy nawet 72 tysięcy (Što je oluja?, 20.07.2015). To liczba przewyższająca czytelników książek, które w Chorwacji sprzedają się w nakładach około kilku tysięcy egzemplarzy ${ }^{12}$, i dorównująca nakładom tygodników. Dzięki własnej stronie Rudan dociera do znacznie większej liczby osób, niż mogłaby poprzez książki; dzięki specyficznej dla siebie strategii wywoływania kontrowersji jej teksty często komentowane są przez inne media. Wolno sądzić, że pisarka doskonale wykorzystuje potencjał bloga do podtrzymywania swojej obecności na rynku mediów.

\section{Telewizja}

Najskuteczniejszym wciąż kanałem komunikacyjnym w sferze publicznej pozostaje telewizja. Osoby pojawiające się w niej szybko stają się rozpoznawalne, a rozpoznawalność jest kluczem do kariery publicznej. Vedrana Rudan jest zapraszana do udziału w programach społeczno-politycznych, które można by zaliczyć do opiniotwórczych. Pisarka pojawia się w nich od ponad dekady. Czasem jej udział jest uzasadniony ze względu na temat kobiet w społeczeństwie i polityce, o czym Rudan pisze dużo; czasem jednak są to kwestie bieżącej polityki czy problemów społecznych. W tych przypadkach odpowiedź na pytanie, dlaczego właśnie Rudan, wydaje się dwojaka. Po pierwsze, jest to postać wyrazista, wyrastająca poza konwencje programu telewizyjnego, chętnie i świadomie je łamiąca. Przytoczę fragment jej rozmowy z Branimirem Biliciem, moderatorem i redaktorem cyklicznej emisji „Puls Hrvatske”:

R: Przeszkadza mi, że zawsze jest pan taki skrzywiony i podkurwiony, nabuzowany. -

B: Bo się boję, kiedy z panią rozmawiam. - R: Nie, no, w ogóle. A z pana taki normalny człowiek, na poziomie, nikt mi w to nie uwierzy. - B: (śmiech) To się pani myli. - R: Tak, i te dziewczyny od charakteryzacji powiedziały mi, że jeśli się ten typ przynajmniej raz w ciągu emisji uśmiechnie, to każda da mi po sto kun. - B: (śmiech) Ha, to dziś pani zarobiła co najmniej trzysta. - R: A ja się cieszę, że pan się śmieje. Bo kiedy tylko ludzie pana widzą na ekranie, od razu pana wyłączają ${ }^{13}$.

11 „Nije lako biti slavan i moćan poput mene. Imam najčitaniji blog na Balkanu...”. Zob. http:// www.rudan.info/tiha-pasja-noc-u-dubrovniku/, 24.12.2016 (dostęp: 8.01.2017).

12 Vedrana Rudan: žena ne może uspjeti niti u jednoj zemlji ako se ne svidi mužjaku, 5.8.2010, http://www.index.hr/black/clanak/vedrana-rudan-zena-ne-moze-uspjeti-niti-u-jednoj-zemlji-ako-sene-svidi-muzjaku/505466.aspx (dostęp: 6.01.2017).

13 „Smeta me da ste vi uvijek tako namršten, tako nadrkani, napaljeni. - B: Pa ja se bojim kad s vama razgovaram. $-\mathrm{R}$ : Ali ne, $\mathrm{i}$ inače. A vi ste normalan, fin čovjek, to me niko neće vjerovat. - B: (Smijeh) To se varate. - R: Da, i ove od šminke su mi rekle, ako se ovaj u emisiji barem jedanput 
To nietypowa rozmowa $\mathrm{w}$ tym miejscu. Zwykle unika się komentowania spraw innych niż temat debaty, nie są przyjęte uwagi odnoszące się do charakteru czy zachowania danej osoby, nie zdarza się też, by zaproszeni goście negatywnie się wypowiadali o moderatorze dyskusji. Ponadto został zburzony scenariusz emisji tego typu, która zakłada, że to moderator zadaje pytania i to on kontroluje scenę. Tymczasem dzięki swemu niecodziennemu zachowaniu Rudan ożywia widowisko i pobudza zainteresowanie programem - oraz sobą samą ${ }^{14}$.

Ale jest też drugi powód zapraszania Rudan do telewizji: w większości programów występuje ona nie jako pisarka; nie wypowiada się o literaturze, lecz o społeczeństwie i o polityce. Bliżej jej zatem do źródłowej dla europejskich intelektualistów postawy Emila Zoli, krzyczącego „Oskarżam!” w obronie Dreyfussa, bliżej do Krleży publicysty czy Dubravki Ugrešić z Kultury kłamstwa. Słusznie czy nie, na razie tej kwestii nie podejmuję; Rudan bierze udział w debacie społecznej jako głos osoby publicznej zatroskanej o los kraju, o sytuację jego obywateli - a więc pisarki zaangażowanej ${ }^{15}$.

Obecność w różnorodnych programach telewizyjnych działa na zasadzie sprzężenia zwrotnego: pisarka zapraszana ze względu na swą popularność i wyrazistość poglądów zyskuje dzięki temu na popularności i na wyrazistości... Tu zatem objawia się wyraźnie dylemat, czemu służy ten element aktywności Rudan: możliwości zabrania głosu czy też tworzenia marki. Znaczna część emisji, w których pojawia się pisarka z Rijeki, to programy typu talk-show. Ta kategoria programów ma charakter rozrywkowy, choć czasem bywa on zamaskowany ambicjami poruszania głębszych tematów. Talk-show mają swoją specyfikę: najczęściej rozmowa toczy się w obecności publiczności w studio, która ma żywo reagować na dyskusję; kontakt z prowadzącą/prowadzącym jest bliższy, mniej formalny, zaś styl wypowiedzi bliższy jest rozmowie potocznej. Udział w takich emisjach trudno wiązać z potrzebą zajęcia stanowiska w istotnej społecznie sprawie. Jest to raczej potrzeba rozpoznawalności, wydatnie wspomagająca obecność w sferze publicznej. Przykładem programu tego typu był Sanja talk show, produkowany przez RTL w latach 2004-2005, ze znacznym sukcesem u widzów ${ }^{16}$. Rudan została zaproszona do programu poświęconego zazdrości (Što je zavist i kako je izbjeći); prowadząca przedstawiła ją jako „pisarkę o ciętym języku, którą

nasmije, svaka će mi dat po sto kuna. - B: (Smijeh) E, danas ste zaradili barem tristo. - R: A meni je drago da se vi smijete. Jer čim vas ljudi vide na ekranu, odmah vas isključuju, samo ono, mrak mrak". Emisja „Puls Hrvatske”, HRT1, 15.03.2012, https://www.youtube.com/watch?v=BKmIdoALnNY, 5'16"-5'40" (dostęp: 6.01.2017).

14 Doskonałą analizę telewizyjnego programu publicystycznego jako widowiska opartego na scenariuszu i z góry założonych rolach, a także kontekst prawny i etyczny tego typu emisji przedstawiła Gordana Škaljac Narančić, Etički prijepori i javna televizija. Studija slučaja: emisija Otvoreno emitirana 21. siječnja 2010. godine, „Medijske studije / Media Studies” 2011, 2 (3-4), s. 106-117.

15 Nie dysponuję pełną listą wystąpień telewizyjnych Vedrany Rudan, byłoby to trudne do zestawienia. Brała udział w emisjach poświęconych np. kwestii aborcji, sytuacji starych ludzi, dyskryminacji kobiet i relacji chorwacko-serbskich.

16 Informacje za: http://maxima-film.hr/sanja/ (dostęp: 6.01.2017). 
niektórzy uwielbiają, a niektórzy wręcz przeciwnie"17. Tym samym został zarysowany profil medialny Rudan, krótka charakterystyka przyjętej przez nią, a może przypisanej jej roli: postaci kontrowersyjnej, budzącej skrajne emocje. Nie jest zatem najistotniejszy przekaz, treść wypowiedzi, ale dramaturgia widowiska.

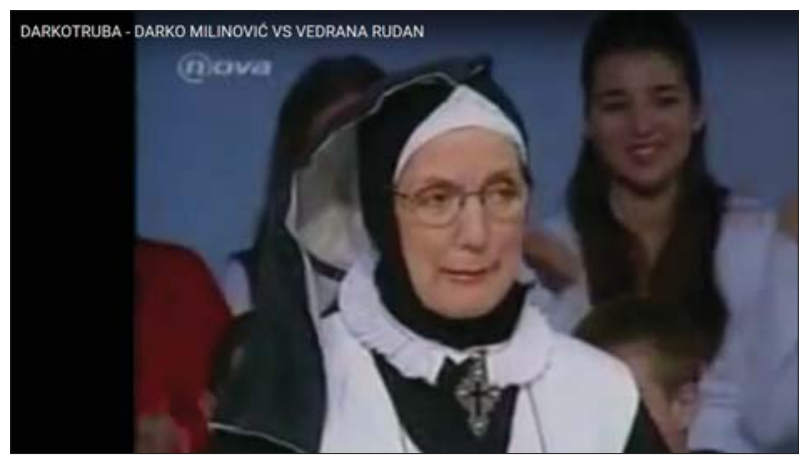

II. 1. Vedrana Rudan w programie U sridu

Źródło: https://www.youtube.com/watch?v=oRU0dc_Eoqw (dostęp: 6.01.2017).

Występy Vedrany Rudan bywają najczęściej starannie wyreżyserowane przez nią samą. Przykładem dość skrajnym była jej rozmowa z Darkiem Milinoviciem, politykiem z partii HDZ ${ }^{18}$, wyemitowana przez komercyjną stację telewizyjną Nova TV w cyklu $U$ srid $u^{19}$ w 2006 roku. Rudan przyszła do studia w przebraniu zakonnicy. Przyjęła też afektowany sposób wypowiadania się, parodiując wyobrażenie siostry zakonnej; pozwoliło jej to zachować dystans do własnego stanowiska, a celem było prawdopodobnie pokazanie poglądów polityka z nielubianej przez nią partii w krzywym zwierciadle ${ }^{20}$.

Dzięki przebraniu pisarka skupiła na sobie uwagę, to ona stała się centralną postacią kontrolującą scenę. Widowisko zostało podporządkowane jej scenariuszowi, a dzięki temu reprezentowane przez nią poglądy wybrzmiały skuteczniej. Jeżeli spojrzymy na widowisko medialne i w ogóle na komunikację w sferze publicznej jak na rywalizację, nie tyle jako starcie opinii, ile jako ring, na którym wygrywa skuteczniejszy, to musimy przyznać, że Vedrana Rudan efektywnie wykorzystuje możliwości stwarzane przez inscenizację telewizyjną. Z kolei media chętniej zapraszają postacie, dzięki którym rośnie oglądalność, nawet za cenę kontrowersji.

17 Sanja Talkshow: štojezavistikakoje izbjeći, https://www.youtube.com/watch?v=uQC9pShL91k, 0'54" (dostęp: 7.01.2017).

18 HDZ, Chorwacka Wspólnota Demokratyczna - centroprawicowa partia polityczna, prowadząca w latach 90., kiedy jej przywódcą był Franjo Tuđman, politykę nacjonalistyczną.

19 Program miał podtytuł Magazyn społeczny, który nie boi się żadnego tematu (http://mojtv.hr/ emisije/212/u-sridu.aspx).

20 Por. sprawozdanie z emisji w portalu Index.hr: http://www.index.hr/vijesti/clanak/vedranarudan-hdzovcu-milinovicu-i-ginekolozi-i-hdz-bave-se-pizdarijama/333693.aspx, 30.11.2006 (dostęp: 8.01.2017). 


\section{Spotkania z czytelnikami}

Kolejnym aspektem obecności Vedrany Rudan w sferze publicznej są spotkania z czytelnikami. Ten rodzaj aktywności tradycyjnie wiąże się z pracą pisarza: towarzyszy promocji książek, festiwalom literackim, udziałom w targach książki i innych imprezach kulturalnych. Autorka Murzynów we Florencji chętnie podróżuje, spotyka się z czytelnikami nie tylko w Chorwacji, ale może nawet częściej bywa zapraszana do Serbii, Bośni, a także innych krajów, w których ukazują się przekłady jej utworów. Spotkania z Rudan zwykle różnią się od ustalonego schematu spotkania z autorem czy promocji książki. Autorka najczęściej starannie reżyseruje widowisko, ustala relacje między sobą, wydawcą i/lub moderatorem oraz publicznością.

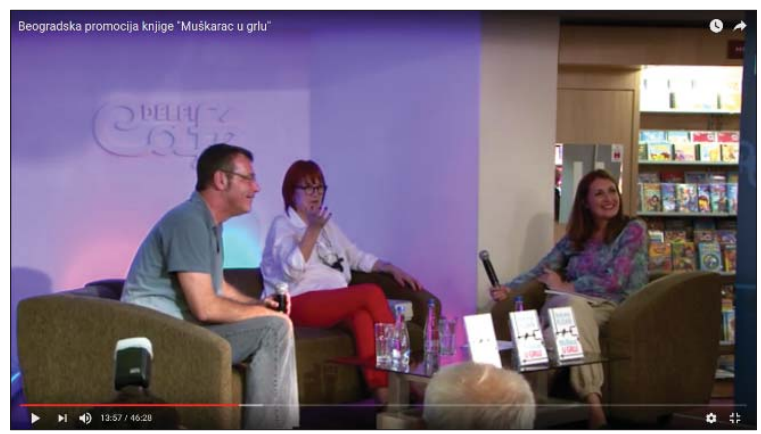

II. 2. Spotkanie promocyjne w Belgradzie

Dobrym przykładem dramaturgii spotkań z Vedraną Rudan jest zapis promocji jej najnowszej książki Muškarac u grlu w belgradzkiej kawiarni Delfi, która miała miejsce 12 września 2016 roku $^{21}$. Najważniejsze moim zdaniem jest stworzenie wrażenia przez autorkę, że jest ,jedną z nas"; pisarka stara się zachowywać tak, by sugerować, że jest „zwyczajną” osobą, nienależącą do establishmentu. Rudan wielokrotnie łamie konwencję spotkania, przerywając rozmówcom, stawiając niewygodne pytania. Nie stroni od przywoływania osobistych, czasem kontrowersyjnych doświadczeń. Kilkakrotnie polemizuje z wizerunkiem pisarza, specjalisty od „ducha”, i z konwencją rozmowy o książce jako produkcie należącym do kultury wysokiej, kultury wykształconych. Chętnie opowiada o przypadłościach zdrowotnych, o nadciśnieniu, lekarstwach, podkreśla swój wiek i starzenie się, nie ukrywa zmęczenia. W jej odpowiedziach na pytania przeplatają się odniesienia do książki i do codzienności, historie z własnego życia. Odniesienia do literatury czy kultury wysokiej, które pojawiają się w wypowiedziach Arsenijevicia, są przez Rudan parodiowane, banalizowane lub odrzucane jako rzekomo obce jej aluzje do obiegu elitarnego. Promowana książka staje się niejako częścią życia, codzienności, i trudno się zorientować, gdzie zaczyna się opowieść

21 Zapis dostępny na portalu YouTube: https://www.youtube.com/watch?v=SvrN8NJm3iY (dostęp: 8.01.2017). 
fikcyjna, a gdzie kończy historia wzięta z doświadczenia. Zacieranie tej granicy charakteryzuje pisarstwo Rudan. Uważam, że jednym z celów takiego zabiegu, a na pewno jednym z najważniejszych celów strategii przyjętej na spotkaniu promocyjnym, jest właśnie stworzenie wrażenia bliskości z czytelnikami i emocjonalne związanie ich z książką. Ilustracja 2 pokazuje scenę, swobodny strój gości spotkania, wygodne siedzenia; chciałem wskazać też na inne aspekty: po pierwsze, rozluźnioną, niemal wesołą atmosferę, rozbawienie widoczne na twarzach głównych aktorów, oraz po drugie, kontakt z publicznością w trakcie rozmowy o książce, nawiązany tym razem spontanicznie przez Rudan.

Inne spotkania, które miałem okazję oglądać na żywo bądź na nagraniach, zazwyczaj charakteryzuje równie dobry kontakt z publicznością, łatwość nawiązywania rozmów, a także dystans do roli pisarza. „Zwyczajność”, wzięta w nawias w poprzednim akapicie, odnosi się, rzecz jasna, do wyobrażenia tego, co zwyczajne; w rozumieniu, w które wpisują się działania Rudan, oznacza nieprzynależenie do establishmentu, kulturalnego bądź politycznego, dystans do wyobrażenia pisarza tworzącego spiżowe dzieło. Bliżej jej zdecydowanie do Bursy z przywołanego w pierwszym przypisie wiersza. Ponadto posługuje się ona językiem potocznym, nie stroniąc od wulgaryzmów. Dystansuje się od stylu wysokiego, intelektualnego, jej wypowiedzi często są dosadne i pozbawione troski o staranność czy polityczną poprawność. Wystąpienia Rudan w czasie tych spotkań to mieszanina sąsiedzkiej rozmowy przy kawie i publicystyki, co jeszcze potęguje wrażenie zwyczajności, bliskości i otwartej komunikacji.

\section{Internet}

Postanowiłem wyróżnić odrębną kategorię „Internet”, obejmującą pozostałe działania w sieci poza blogiem. Podstawowa forma obecności w Internecie to oczywiście aktywność w mediach społecznościowych. Vedrana Rudan od kilku lat prowadzi oficjalną stronę na Facebooku ${ }^{22}$, zaś jej administratorem jest jej syn, Slaven Hrvatin. Do dnia 9 stycznia 2017 roku jej fanpage uzyskał ponad 180 tysięcy polubień, a ponad 35 tysięcy osób aktywnie korzystało z tej strony. Fanpage na portalu Facebook jest kolejną formą prowadzenia przez Rudan relacji z czytelnikami/odbiorcami jej tekstów, komentowania swojej kariery i otaczającej rzeczywistości, ale także skutecznym sposobem tworzenia czy też podtrzymywania wizerunku.

Widoczne na ilustracji 3 zdjęcie profilowe przekazuje jednoznaczną informację wizualną: popularna autorka podpisuje swoją książkę, czeka rząd czytelników. Zdjęcie sugeruje popularność, dobry kontakt z publicznością, mocną pozycję na rynku książki.

Portal Facebook, podobnie jak blog, pozwala na łączenie kanału tekstowego i wizualnego. Ponieważ obraz łatwiej dociera do odbiorcy i wywołuje szybszy efekt, jego użycie umożliwia skuteczniejsze oddziaływanie. Tym bardziej że szybkie przetwarzanie informacji, z pominięciem analizy tekstualnej, łatwiej

22 Zob. https://web.facebook.com/VedranaRudanBlog/. 


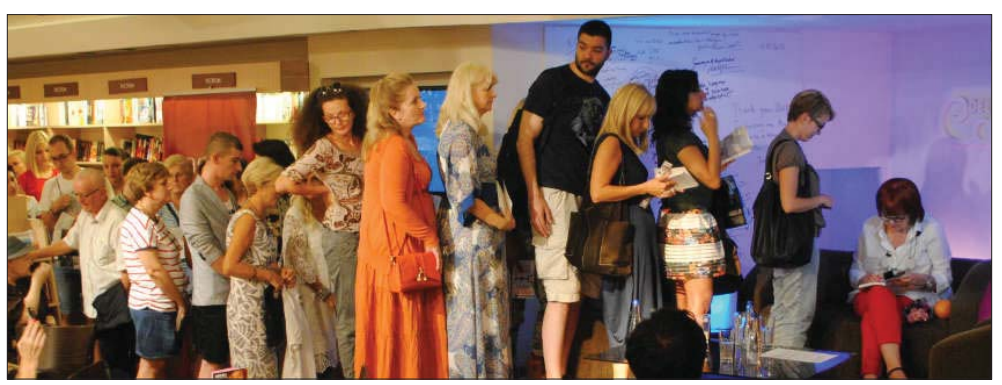

II. 3. Zdjęcie profilowe V. Rudan na portalu Facebook

pobudza emocje i tym samym wzmacnia pożądany efekt. W mediach społecznościowych obraz ma jeszcze większe znaczenie niż na blogu; do tego warto dodać dane o wysokiej liczbie aktywnych użytkowników (,polubieniach”), podkreślające popularność autorki. Działania podejmowane przez nią w rozmaitych mediach można porównać do pozycjonowania - to termin zaczerpnięty z praktyki medialnej, oznaczający zwiększanie widoczności strony internetowej, tak by częściej wyświetlała się w wyszukiwarkach internetowych i dzięki temu przyciągała uwagę użytkowników. Vedrana Rudan działa podobnie: korzystając z rozmaitych mediów pośredników, nie tylko z literatury, zwiększa skuteczność komunikacyjną, ale także osiąga cele komercyjne ${ }^{23}$. Można wyciągnąć wniosek, iż skuteczne istnienie w polu literackim wiąże się z efektywnym pozycjonowaniem własnej osoby pisarza/pisarki jako rozpoznawalnej marki, a dopiero kolejnym krokiem jest rezonans, jaki przynoszą utwory literackie. Wniosek ten potraktuję jednak jako tymczasowy, ponieważ wymaga on przedyskutowania w perspektywie zasygnalizowanej na wstępie kategorii pisarza zaangażowanego/pisarki zaangażowanej.

Porównania aktywności w polu literackim do działań medialnych nie powinny zmylić. Chodzi o podobieństwo strategii, ale niekoniecznie celów. Tam, gdzie w przypadku mediów takich jak: portale informacyjne, firmy internetowe itp. idzie głównie o maksymalizację zysków finansowych, w przypadku pisarzy, partii politycznych, organizacji o profilu ideologicznym ważniejsze jest dążenie do dotarcia z przekazem ideowym do jak najszerszego kręgu odbiorców. Tworzenie marki, rozpoznawalność osoby pisarza wiąże się z pewnością z chęcią sprzedaży jak największej liczby książek - ale także z przekonaniem jak najszerszego kręgu odbiorców do swoich racji.

22 stycznia 2012 roku w Chorwacji odbyło się referendum, na którym obywatele mieli zdecydować, czy popierają akcesję państwa do Unii Europejskiej, czy nie. Nastroje przedreferendalne były dość negatywne wobec dołączenia do Unii, pomimo intensywnej kampanii rządu; rząd chorwacki doprowadził nawet

23 Aaker pisze, że dobrze umocowana marka ułatwia prowadzenie strategii na różnych polach i pozwala na maksymalizację osiągnięć (D. Aaker, op. cit., s. 7 i nast.). Tak jest w przypadku Rudan - niezależnie od celów (maksymalizacja zysku, szerzenie przekazu ideowego) wykorzystanie różnych kanałów i pól daje synergię działania, co z kolei skutecznie zwiększa rozpoznawalność marki. 


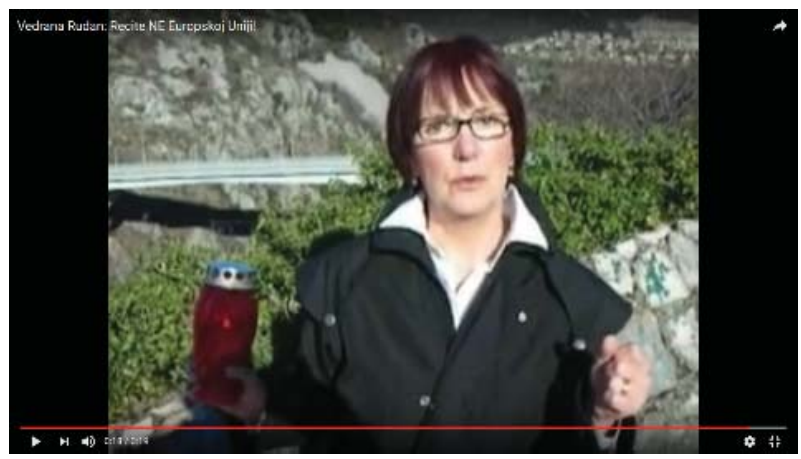

II. 4. Kadr ze spotu przedreferendalnego Vedrany Rudan (https://www.youtube.com/ watch?v=oC5ToDb5GwE, dostęp: 9.01.2017)

do zmiany ustawy o referendum, tak aby zapewnić pozytywny rezultat głosowania. Vedrana Rudan dzień wcześniej zamieściła na portalu YouTube krótki spot, w którym wypowiedziała się zdecydowanie przeciwko akcesji.

Przekaz brzmiał: „Moi drodzy, dzisiaj nasi EU-niewolnicy walą w nas ze wszystkich armat. Idźmy jutro na referendum i zakreślmy «NIE!», żeby Nasza Ojczyzna nie spoczęła niebawem w grobie"24. Na zaprezentowanym na ilustracji 4 ujęciu ze spotu widać wykorzystany rekwizyt: znicz, mający oczywiście podkreślić wagę słów pisarki. Nie był to może wyrafinowany pomysł, jednakże zasada działania jest podobna do wcześniejszych: wykorzystać możliwości, jakie daje Internet, aby rozpowszechniać przekaz wizualno-słowny, dostępny niemal bez ograniczeń.

Ostatni przykład uzmysławia, jak ważnym aspektem aktywności Vedrany Rudan jest pewien kompleks ideowy, przebijający się ze wszystkich form jej działań. Spot przedreferendalny nie mógł być obliczony na zwiększanie zysku ze sprzedaży książek, zwłaszcza że wiązał się z pewnym ryzykiem wizerunkowym.

\section{Happening}

Posłużyłem się kategorią z obszaru sztuki na określenie działań, które nie mają wymiaru artystycznego, jednakże wiążą się z podobnym rozumieniem praktyki. Chodziłoby zatem o posiadającą wewnętrzną strukturę dramatyczną sekwencję działań, które mają inne znaczenie od pragmatycznego, dosłownego. W ten sposób działający, agens, pragnie zwrócić uwagę na określone zjawiska czy sensy, do których można dotrzeć skuteczniej niż poprzez dosłowny komunikat ${ }^{25}$.

24 „Dragi moji, danas naši EU-rorobovlasnici pucaju na nas iz svih topova. Izađimo sutra na referendum i zaokružimo «NE!» da ne bi uskoro Lijepa Naša počivala u miru”. Zob. https://www.youtube.com/watch?v=oC5ToDb5GwE, 0’02"-0'18” (dostęp: 9.01.2017).

25 Na temat happeningu i jego specyfiki w odróżnieniu od innych form działań teatralnych zob. G. Dziamski, Od teatralizacji sztuki do teatralizacji kultury, „Dyskurs 2. Pismo Naukowo-Artystyczne 
W lipcu 2016 roku, przed przyspieszonymi wyborami parlamentarnymi, powstała partia polityczna SMS - Sasvim mala stranka (Całkiem Mała Partia). Nazwa i sposób działania wskazują jasno, że celem nie było wejście do gry politycznej na zasadach obowiązujących w polu polityki, nie chodziło o faktyczne wejście do parlamentu. SMS jest skrótem niepoważnym, podobnie jak spoty przedwyborcze czy medialne wypowiedzi członków partii; dla przykładu: SMS poszukiwała kandydatów/kandydatek na posłów/posłanki poprzez ogłoszenie na portalu Facebook i w mediach ${ }^{26}$, spoty przypominały czołówki teleturniejów bądź reklam ${ }^{27}$. Wyraźnie ujawnia się pragnienie sparodiowania kampanii wyborczych i podkopania wiary w uczciwość działań partii politycznych, od początku niepodległości na przemian sprawujących rządy w Chorwacji. Motorem działań byli: Đelo Hadžiselimović, wieloletni redaktor w chorwackiej telewizji, Robert Zuber, dziennikarz i redaktor telewizyjny, oraz Ella Dvornik, młoda chorwacka blogerka modowa. Do nich dołączyła Vedrana Rudan ${ }^{28}$. Nikomu z kandydatów nie udało się przekroczyć progu wyborczego, ale nie to było zamiarem happeningu. Według oświadczenia założycieli SMS najważniejszym celem ich działań jest zwrócenie uwagi chorwackich wyborców na konieczność zajęcia się polityką. Przypominają stare powiedzenie: jeśli ty nie zajmiesz się polityką, ona zajmie się tobą ${ }^{29}$. Głos SMS w przewrotny i prześmiewczy sposób ma za zadanie wyrwać obywateli z marazmu i pustego narzekania i skłonić ich do podjęcia działań ku zmianie lub choćby do aktywnego analizowania sceny politycznej i przejęcia odpowiedzialności za stan kraju.

\section{Literatura}

Tym jednak, co sprawiło, że Vedrana Rudan weszła na drogę sławy i stała się postacią znaną nie tylko w Chorwacji, była literatura. Rozgłos przyniosła jej pierwsza powieść z 2002 roku, a kolejne publikacje jedynie wzmacniały rozpoznawalność autorki. Warto przyjrzeć się teraz, na ile wizerunek medialny związany z marką Rudan koresponduje z tekstami literackimi; czy jest on jedynie strategią obliczoną na popularność i sprzedaż, wpisującą się w profil bycia celebrytką, czy też stanowi kontynuację wątków zawartych w przekazie literackim, tyle że z wykorzystaniem innych mediów i innych technik. Skupię się przy tym na pierwszej

ASP we Wrocławiu", s. 12 i nast., http://www.asp.wroc.pl/?module=StaticContent\&controller=Main \&id=923\&_seoName=Dyskurs +2 (dostęp: 5.01.2017).

26 Zob. http://www.jutarnji.hr/izbori2016/izborne-vijesti-2016/sasvim-mala-stranka-trazikandidate-zelite-li-iskusiti-slast-borbe-u-politickoj-areni/4600781/, 16.08.2016 (dostęp: 9.01.2017).

27 Zob. http://www.jutarnji.hr/vijesti/hrvatska/video-sasvim-mala-stranka-objavila-predizbornispot-ja-vas-obozavam-bravo-sms/4620995/, 14.08.2016 (dostęp: 9.01.2017).

28 Zob. Ella Dvornik, Đelo Hadžiselimović i Vedrana Rudan se kandidirali na parlamentarnim izborima, http:/www.index.hr/black/clanak/ella-dvornik-djelo-hadziselimovic-i-vedrana-rudan-sekandidirali-na-parlamentarnim-izborima/912680.aspx, 13.08.2016 (dostęp: 9.01.2017).

29 „Najvažnija poruka SMS-a je - izađite na birališta i dajte svoj glas, ne nužno za nas, glasajte za bilo koga, za onoga za koga smatrate da je najbolji. Samo izađite i dajte svoj glas. Stara i točna izreka kaže: Ako se ne bavite politikom, politika će se baviti Vama”. Zob. https://www.facebook.com/ sasvimmalastranka/ (dostęp: 9.01.2017). 
powieści, wyznaczającej moim zdaniem paradygmat pisarski Rudan. Ponieważ niniejszy tekst nie jest poświęcony analizie pisarstwa chorwackiej autorki, zajmę się jedynie wybranymi zagadnieniami stylu, aby wskazać na możliwe powiązania między rożnymi aspektami jej strategii.

Gdy minie ta noc, odejdę od Kikiego. Zostawię go. Zamknę za sobą drzwi. Otworzę nową stronę. Spalę za sobą wszystkie mosty. Wypierdolę dotychczasowe życie. Wyślę Kikiego w pizdu. Ruszę nową drogą. Odetchnęliście. Słyszę was. Mówicie. Super. Jednak coś w tym jest. Nie leży głupia cipa w ciemną noc, wcale nie jest ciemna noc. Jestem w łóżku i bez sensu nie śpię. Coś ją gryzie. Dalej! Słuchamy! Co cię gryzie, stara krowo?30

Wybrany fragment otwiera opowieść Tonki Babić - bohaterki i narratorki powieści. Charakteryzuje go kilka typowych dla prozy Rudan procedur. Przede wszystkim wykorzystanie wulgaryzmów w bardzo dużym natężeniu; wulgaryzacja języka staje się naturalnym sposobem wypowiadania się narratorki. Czemu to służy? Ilustruje to powyższy ciąg wypowiedzi. Siedem krótkich zdań odnosi się do tej samej czynności i oznacza: „Zostawię męża i zakończę dotychczasowe życie”. Dwa zdania to prosty opis planowanej czynności: „Odejdę od Kikiego” i „Zostawię go”. Trzy kolejne zbudowane są z frazemów, utartych zwrotów denotujących zmianę życiową: "Zamknę za sobą drzwi” (tu znaczenie dosłowne też jest możliwe), „Otworzę nową stronę”, „Spalę za sobą wszystkie mosty”. To zwroty wyświechtane, używane najczęściej w literaturze lub eseistyce, obarczone nutą patosu, podniośle sugerujące czyn nieodwracalny. Kolejne zdania przynoszą załamanie stylu: „Wypierdolę dotychczasowe życie”, „Wyślę Kikiego w pizdu”. Wulgarne zdania denotują tę samą czynność, ale ich konotacja jest oczywiście odmienna. Wprowadzenie przekleństw obniża styl wypowiedzi, przełamuje patos narracji, odrywa od stereotypowego sposobu referowania na rzecz zaskoczenia, wyrwania z językowej, literackiej monotonii. Autorka osiąga podwójny efekt: sygnalizuje dystans wobec modelu „literatury pięknej”, wyobrażenia urobionego przez szkolny kanon ,,pięknego” pisania, poprawnego i eleganckiego wypowiadania się; ponadto sytuuje swoją narrację po stronie potoczności, codzienności, dając czytelnikowi do zrozumienia, że będzie opowiadać o rzeczach bliskich ,zwyczajnemu" odbiorcy. Uważam, że wulgaryzacja w hiperboliczny sposób konotuje właśnie codzienność, potoczność, a także ma wywoływać emocje. Wulgaryzacja dotyka też postaci samej bohaterki, która w wyobrażonym dialogu nazywana jest „głupią cipą”, „starą krową". Zamiar jest zapewne podobny: obniżenie nastroju, odarcie bohaterki z wyjątkowości i opisanie jej jak zwyczajnej osoby. W swej opowieści Tonka Babić chętnie podkreśla szczegóły swojej cielesności, zwłaszcza negatywnych czynników: wspomina klimakterium, nadciśnienie, zepsute zęby, obwisłe piersi. Wszystko to jest zaprzeczeniem - „ładnej” literatury, ale

30 „Kad mine ova noć, otići ću od Kikija. Ostavit ću ga. Zaključati vrata za sobom. Otvoriti novu stranicu. Zapaliti sve mostove iza sebe. Odjebati bivši život. Poslati Kikija u kurac. Krenuti u novo jutro. Odahnuli ste. Čujem vas. Govorite. Super. Ipak ima nešto. Ne leži glupa pička u gluho doba noći, uopće nije gluho doba noći, u krevetu sam i budna bez veze. Nešto je grize. Ajmo! Slušamo! Što te grize, stara kravo?”. V. Rudan, Uho, grlo, nož, Beograd 2002, s. 10. Podaję cytat w swoim tłumaczeniu, mimo że istnieje przekład polski, lecz wydaje mi się on zbyt łagodny, ugrzeczniony, jeśli chodzi o wulgaryzmy i dosadność Rudan. 
też dominującego w popkulturowych mediach wizerunku kobiety, powszechnego wypierania starzenia się, ukrywania niedoskonałości. Bohaterka staje się figurą „zwyczajnej” kobiety w średnim wieku, postaci, która świadomie nie dąży do realizacji wizualnego ideału popkultury.

Drugim czynnikiem typowym dla pisarstwa Rudan, zarówno dla prozy, jak i publicystyki, jest dynamika wypowiedzi. Osiąga ją dwojako. Po pierwsze, często stosuje zdania urywane, równoważniki zdań, wypowiedzenia złożone tylko z jednego wyrazu, jak w powyższym cytacie: „Odetchnęliście. Słyszę was. Mówicie. Super. Jednak coś w tym jest”. Czy dalej: „Dalej! Szybciej! Pije?! Pierdoli się z innymi?! Wcale nie pierdoli?! Tłucze cię? Dlaczego odchodzisz?! W twoim wieku? A gówno odchodzisz!’’31. Takich fragmentów jest bardzo dużo; zdania złożone są rzadsze, a i wówczas często mają strukturę asyndetonu. I znów są to wypowiedzi sugerujące odejście od stylu literackiego, uważanego za staranny i poprawny. Narracja u Rudan naśladuje potoczną wypowiedź bądź tok myśli, a ponadto częste wykorzystanie wykrzykników i znaków zapytania stwarza wrażenie wypowiadania nacechowanego emocjami, modulowanego tonu, dodatkowej akcentuacji na poziomie zdania czy akapitu. Po drugie, narratorka prowadzi nieustanny dialog z wyobrażonymi rozmówcami; partnerem tej rozmowy są jacyś „oni”. Nie jest to więc solilokwium, wypowiedź w pierwszej osobie liczby pojedynczej, lecz fikcyjna rozmowa pełna pytań, zwrotów adresatywnych, polemik. W ten sposób wypowiedź dodatkowo zyskuje dynamikę, a ciężar narracji przenosi się z typowej modernistycznej fiksacji na podmiocie na ,ja", na sferę interakcji.

Drugi fragment odnosi się do kolejnej specyfiki stylu Rudan.

W odpisie z metryki mam napisane - Imię ojca: Živorad Babić. Stara jakoś nie mówiła o szczegółach. Ja tylko przypuszczam, że Živko wyruchał moją starą w pięknym żydowskim mieszkaniu. Wolę to od jebania w parku w Opatii albo w ubeckiej kancelarii. Ja nigdy nie wybaczyłam swojej starej, że nie wzięła żydowskiego mieszkania. Choć mogła wybierać. Była kimś. Szalała za Partią. Ha, gdyby jej pięćdziesiąt któregoś roku, ha, nie wyruchał oficer UB, umarłaby jako dziewica. Dla niej Partia była wszystkim. Ona, babcia i ja spędziłyśmy życie w piwnicy ${ }^{32}$.

Narrację Tonki Babić cechuje przeplatanie trywialnych i dramatycznych tematów; obok wywodu o szkodliwości czekolady czy torebkach od Armaniego ciągnie się kwestia mienia pożydowskiego czy gwałtu na matce. Co więcej, opowieść pełna jest dygresji; nie ma w niej dominującego wątku, głównej historii, fabuły. Istnieją ramy opowieści: od początkowej deklaracji bohaterki, że to ostatnia noc przed rozstaniem z mężem, po końcowe przyznanie, że wszystko to było fikcją. Jednakże opowieść tocząca się $\mathrm{w}$ tak zarysowanych ramach to narracja

${ }^{31}$ „Ajmo! Brže! Pije?! Jebe druge?! Ne jebe uopće?! Mlati te? Zašto odlaziš?! U tvojim godinama? Odlaziš kurac!”. Ibid., s. 10.

${ }^{32}$ „Pa mi u izvodu iz matične knjige piše - Ime oca: Živorad Babić. Stara baš i nije pričala detalje. Ja samo pretpostavljam da je Živko moju staru naguzio u lijepom židovskom stanu. To mi je prihvatljivije od jebačine u opatijskom parku ili kancelariji Udbe. Ja mojoj staroj nikad nisam oprostila što je odbila židovski stan. Iako je mogla birati. Bila je faca. Luda za Partijom. Da je pedeset i neke, ha, nije pojebao oficir Udbe, umrla bi nevina. Njoj je Partija bila sve. Ona, nona i ja, mi smo život provele u podrumu". Ibid., s. 20. 
dygresyjna, to mozaika, pomieszanie rejestrów. Dzięki temu znów narracja przykuwa uwagę poprzez wprowadzanie coraz to nowych elementów, minihistorii, a ponadto naśladuje tok rozmowy potocznej czy rozmyślań: nieuporządkowanych, wypełnionych zaskakującymi asocjacjami.

W powyższym cytacie uwidacznia się jeszcze jeden stały temat podejmowany przez Rudan: cielesność, a szczególnie seks. Bardzo wiele miejsca zajmuje seks, najczęściej opisywany wulgarnie lub dosłownie, pozbawiony otoczki romantyczności czy tajemniczości, jaką stworzyła wokół niego kultura europejskiego modernizmu. U Rudan seks to ,jebanie”, „lizanie”, ,pierdolenie” - te leksemy i ich pochodne dominują w obrazach relacji seksualnych. Taki sposób mówienia/pisania o seksualności kojarzony jest z męskością, to słowa dozwolone dla mężczyzn, ale nie kobiet, tak więc autorka przełamuje tabu podwójnie, burząc genderowy stereotyp języka seksualności ${ }^{33}$. Felietony Rudan i wpisy na blogu również gęste są od słownictwa związanego z seksualnością; porównania do stosunku to ulubiony chwyt retoryczny w jej publicystyce.

W podsumowaniu tej krótkiej analizy stylistyki chorwackiej pisarki chciałbym się zastanowić, czemu służą omówione wyżej, charakterystyczne dla Rudan aspekty jej pisania i w jaki sposób korespondują ze strategiami w sferze publicznej.

\section{Strategie karnawalizacji}

Rudan często bywa określana jako pisarka „kontrowersyjna”. Widzieliśmy na wcześniejszych przykładach, że starannie pielęgnuje ona to wrażenie, łamiąc konwencje scenariuszy, kontrolując scenę publiczną i wprowadzając własne zasady, w literaturze zaś posługując się wulgaryzmami niepasującymi do ,kobiecego pisania”. We wszystkich kanałach komunikacyjnych, począwszy od tekstów literackich, poprzez bloga, a skończywszy na emisjach telewizyjnych i działaniach w sferze politycznej, Vedrana Rudan konsekwentnie wykorzystuje te same strategie. Czas, żeby je podsumować.

Po pierwsze, stara się przedstawiać odbiorcom jako osoba „zwyczajna”, ,jedna z nas", a więc postać nieprzynależąca do dyskursu podziałów politycznych, uznawanych przez nią za pozorne i niemające wiele wspólnego z rzeczywistymi problemami obywateli kraju. Wyraźnie dystansuje się wobec elit politycznych czy kulturalnych, nie uznaje autorytetów w polu literackim. Publicystyczne teksty odnoszą się do „onych”; za zły stan sfery publicznej, ekonomii, edukacji winę mają ponosić właśnie politycy, hierarchowie Kościoła katolickiego, wysocy urzędnicy, a więc ci wszyscy, którzy kontrolują centra mocy. Rudan, wykorzystując możliwości stwarzane przez różne sytuacje, co starałem się ukazać na przykładach ze spotkania autorskiego, programu społeczno-politycznego i wypowiedzi literackiej, podkreśla swoją opozycję wobec „onych” i sytuuje się po

33 O genderowym wymiarze strategii pisania Vedrany Rudan, w odniesieniu do innej powieści, pisze I. Bujan, Pozicioniranje ženskog subjekta u suvremenom hrvatskom (pseudo)autobiografskom diskursu, „Croatica” 2013 (57), 37, s. 153-173. 
stronie „Zwykłych ludzi”. Najprawdopodobniej taka pozycja w polu medialnym ma zapewnić jej zaufanie odbiorców, a przy tym skuteczniejsze oddziaływanie jej przekazu ideowego.

Po drugie, łamiąc konwencje i narzucając swoje scenariusze, pisarka zapewnia sobie uwagę odbiorców. Jej wystąpienia przeradzają się często w happeningi bądź widowiska, które burzą rutynę i pobudzają emocje, a więc wpływają na lepszy odbiór przekazu. Innym zyskiem takiej strategii jest rozpoznawalność publiczna, przekładająca się zarówno na sprzedaż książek, jak i konsolidację zwolenników postaw ideowych Rudan.

Po trzecie, wprawne oko zauważy elementy charakterystyczne dla zabiegu karnawalizacji. Świat kreowany przez Rudan to może nie tyle świat na opak, ile rzeczywistość wyrwana z utartych kolein: proza odbiegająca od , literatury pięknej” i ,kobiecego pisania”; emisja telewizyjna, w której zaproszona osoba wypytuje i krytykuje moderatora; partia polityczna poszukująca kandydatów na posłów przez ogłoszenie na portalu społecznościowym. To dosadne, wulgarne komentowanie rzeczywistości, nieukrywające się za fasadą stosownych słów. Zwraca uwagę wreszcie nadreprezentacja tematów, obrazów związanych z czynnościami typowymi dla czasu karnawału: cielesności i przede wszystkim seksualności. Na poziomie stylistycznym uderzającym zabiegiem Rudan jest hiperbolizacja, nadmiar, powodujący wrażenie przesady i ostrego przerysowania opisywanych wątków. Oczywistym celem staje się w ten sposób krytyka istniejącego porządku, czy to chodzi o relacje w polu literackim, czy o kwestie polityczne bądź społeczne.

Można by zatem powiedzieć, że wyrywając odbiorców z letargu przyzwyczajeń konsumentów mediów, Vedrana Rudan narzuca swoje scenariusze, by zmusić do krytycznego spojrzenia, zastanowienia się, zwrócenia uwagi na przerysowaną, emocjonalną, a przez to efektywniej docierającą do nich sytuację. Warto docenić spójność strategii i przekazu, jaka charakteryzuje aktywność pisarki na wszystkich polach. W ten sposób zwiększa ona swoje szanse na to, że marka Rudan ${ }^{\mathrm{TM}}$ będzie wzbudzać większe zaufanie dzięki wiarygodności potwierdzanej przez różnorodną aktywność.

Na zakończenie tej analizy chciałbym jednak zwrócić uwagę na dwie kwestie budzące wątpliwości co do omawianych strategii. Pierwsza odnosi się do zabiegu karnawalizacji - trudno orzec, na ile świadomego. Karnawał w dawnej kulturze był społecznym wentylem bezpieczeństwa: okresem kontrolowanego, rytualnego buntu, po którym wszystko wracało na dawne tory. Strategie Rudan rodzą niebezpieczeństwo, że protest skonwencjonalizuje się w działaniach widowiskowych, a spektakl przerodzi się w czasowe wyładowanie złości, nie powodując głębszej zmiany. Druga kwestia ma większą jeszcze wagę. Otóż podkreślanie „,zwyczajności" i bardzo mocne akcentowanie sprzeciwu wobec elit zbliża Rudan do nurtów populistycznych. W niniejszym artykule przyjąłem, że zajmować się będę jedynie strategią (czyli pytaniem, jak Rudan oddziałuje), a nie zawartością ideową (pytaniem, co chce przekazać), jednak postawa populistyczna wiąże się nie tylko z treścią komunikatów społecznych, lecz także ze strukturą opisywanego świata, odrzucającą to, co na górze hierarchii. 
I wracając jeszcze do dylematu zarysowanego we wstępie - między negacją spiżowego wizerunku pisarza w wykonaniu Bursy a troską o infantylizację i komercjalizację literatury w esejach Dubravki Ugrešić: sądzę, że Vedrana Rudan wpisuje się w profil pisarki zaangażowanej. Powierzchownie nie kojarzy się z typem intelektualistki przejętej losami świata właśnie ze względu na koncentrację na zwyczajności, banalności, detalu życia codziennego. Jednakże uparte poszukiwanie coraz to nowych kanałów oddziaływania, spójne strategie wywierania wpływu oraz polityzacja przekazu wspierają to twierdzenie.

Kolejnym krokiem powinna być analiza ideowego aspektu jej działań, ale to wymaga odrębnego, pogłębionego tekstu. W każdym razie nie wpisuje się ona w profil pisarki-celebrytki, poszukującej rozgłosu i wyłącznie zysku. Działania Rudan funduje pewna wizja społeczno-polityczna, którą stara się ona głosić przy wykorzystaniu dostępnych współcześnie kanałów. Inną sprawą jest to, czy się z ową wizją zgadzamy, czy też nie ${ }^{34}$.

\section{Bibliografia}

Aaker D., Aaker on Branding: 20 Principles that Drive Success, New York 2014.

Bourdieu P., Ontologie politique de Martin Heidegger, Paris 1988.

Bourdieu P., Reguty sztuki. Geneza i struktura pola literackiego, przeł. A. Zawadzki, Kraków 2001.

Bujan I., Pozicioniranje ženskog subjekta u suvremenom hrvatskom (pseudo)autobiografskom diskursu, „Croatica” 2013 (57), 37, s. 153-173.

Bursa A., Poeta, http://literatura.wywrota.pl/wiersz-klasyka/3421-andrzej-bursa-wybor-wierszy.html (dostęp: 23.02.2017).

Charle Ch., La naissance des ,, intellectuels”, 1880-1900, Paris 1990.

Dziamski G., Od teatralizacji sztuki do teatralizacji kultury, „Dyskurs 2. Pismo Naukowo-Artystyczne ASP we Wrocławiu", s. 128-145, http://www.asp.wroc.pl/? module $=$ StaticContent $\&$ controller $=$ Main $\& i d=923 \& \_$seoName $=$Dyskurs +2 (dostęp: 5.01.2017).

Huzak S., Stvaranje nove marke turističeke destinacije: primjer Hrvatske, „Acta Turistica Nova" 3 (2009), 2, s. 227-268.

Kolanović M., Udarnik! Buntovnik? Potrošač... Popularna kultura i hrvatski roman od socijalizma do tranzicije, Zagreb 2011.

McQuail D., Teoria komunikowania masowego, przeł. M. Bucholc, A. Szulżycka, Warszawa 2008.

Rudan V., Uho, grlo, nož, Beograd 2002.

Sartre J.-P., Qu'est-ce qu'une littérature engagée?, Paris 1946.

Škaljac Narančić G., Etički prijepori i javna televizija. Studija slučaja: emisija Otvoreno emitirana 21. siječnja 2010. godine, „Medijske studije / Media Studies” 2011, 2 (3-4), s. 106-117.

Ugrešić D., Czytanie wzbronione, przeł. D.J. Cirlić, Izabelin 2003.

${ }^{34}$ Dziękuję dr Ewie Wróblewskiej-Trochimiuk za lekturę rękopisu i ważne uwagi, które pomogły mi dopracować tekst. 
Źródła internetowe:

http://www.index.hr/black/clanak/ella-dvornik-djelo-hadziselimovic-i-vedrana-rudan-se-kandidirali-na-parlamentarnim-izborima/912680.aspx, 13.08.2016 (dostęp: 9.01.2017).

http://www.index.hr/black/clanak/vedrana-rudan-zena-ne-moze-uspjeti-niti-u-jednoj-zemlji-ako-se-ne-svidi-muzjaku/505466.aspx (dostęp: 6.01.2017).

http:/www.index.hr/vijesti/clanak/vedrana-rudan-hdzovcu-milinovicu-i-ginekolozi-i-hdz-bave-se-pizdarijama/333693.aspx, 30.11.2006 (dostęp: 8.01.2017). http://www.jutarnji.hr/izbori2016/izborne-vijesti-2016/sasvim-mala-stranka-trazi-kandidate-zelite-li-iskusiti-slast-borbe-u-politickoj-areni/4600781/, 16.08.2016 (dostęp: 9.01.2017).

http://www.jutarnji.hr/vijesti/hrvatska/video-sasvim-mala-stranka-objavila-predizborni-spot-ja-vas-obozavam-bravo-sms/4620995/, 14.08.2016 (dostęp: 9.01.2017). http://www.rudan.info/odustajem/ (dostęp: 6.01.2017).

http://www.rudan.info/tiha-pasja-noc-u-dubrovniku/, 24.12.2016 (dostęp: 8.01.2017). https://web.facebook.com/VedranaRudanBlog (dostęp: 9.01.2017). https://www.facebook.com/sasvimmalastranka/ (dostęp: 9.01.2017). https://www.youtube.com/watch?v=BKmIdoALnNY (dostęp: 6.01.2017). https://www.youtube.com/watch?v=oC5ToDb5GwE (dostęp: 9.01.2017). https://www.youtube.com/watch? $\mathrm{v}=\mathrm{oC} 5 \mathrm{ToDb} 5 \mathrm{GwE}$ (dostęp: 9.01.2017). https://www.youtube.com/watch?v=oRU0dc_Eoqw (dostęp: 6.01.2017). https://www.youtube.com/watch?v=SvrN8NJm3iY (dostęp: 23.02.2017). https://www.youtube.com/watch?v=SvrN8NJm3iY (dostęp: 8.01.2017). https://www.youtube.com/watch?v=uQC9pShL91k (dostęp: 7.01.2017). http://maxima-film.hr/sanja/ (dostęp: 6.01.2017). 